\title{
On the Evolution of the Biological Framework for Insight
}

\author{
Claudio Neidhöfer (D)
}

Institute of Medical Microbiology, Immunology and Parasitology, University of Bonn, 52127 Bonn, Germany; claudio.neidhoefer@ukbonn.de

\begin{abstract}
The details of abiogenesis, to date, remain a matter of debate and constitute a key mystery in science and philosophy. The prevailing scientific hypothesis implies an evolutionary process of increasing complexity on Earth starting from (self-) replicating polymers. Defining the cut-off point where life begins is another moot point beyond the scope of this article. We will instead walk through the known evolutionary steps that led from these first exceptional polymers to the vast network of living biomatter that spans our world today, focusing in particular on perception, from simple biological feedback mechanisms to the complexity that allows for abstract thought. We will then project from the well-known to the unknown to gain a glimpse into what the universe aims to accomplish with living matter, just to find that if the universe had ever planned to be comprehended, evolution still has a long way to go.
\end{abstract}

Keywords: evolutionary biology; astrobiology; philosophy of biology; epistemology

\section{Introduction}

Our aim in this work is to approach the lead question of what the universe aims

Citation: Neidhöfer, C. On the

Evolution of the Biological

Framework for Insight. Philosophies 2021, 6, 43. https://doi.org/10.3390/ philosophies6020043

Academic Editors: Rainer

Zimmermann and Marcin

J. Schroeder

Received: 1 April 2021

Accepted: 19 May 2021

Published: 21 May 2021

Publisher's Note: MDPI stays neutral with regard to jurisdictional claims in published maps and institutional affiliations. to accomplish with living matter from an evolutionary biology perspective and, hence, focus on the capacity of the human mind to handle the issue of the role of life in the universe. After addressing the question of the reducibility of biological phenomena, we will introduce some of the most important milestones in evolutionary history. We will examine the evolution of known life, focusing in particular on early life, major evolutionary breakthroughs (often attributed to symbiotic labour-splitting synergistic developments), and finally the evolution of the biological framework that allows for perception and reflection. As a result we will have acquired perspective that allows us to examine the limitations of our knowledge-building instruments and discuss the lead question.

\section{Results and Discussion}

\subsection{Reducibility of Biological Phenomena}

As physics is the study of how matter acts and reacts to various forces and aspects of the world and the universe, it not only has massive implications for the biological sciences, but has actually growingly taken over the latter at an increasing pace in the last decades, causing the reduction of a large part of the autonomous theories of the science of life and living beings to basic theories of a physical nature.

This has therefore lead to numerous debates in the philosophy of biology on whether and which branches of biology can be reduced to molecular biology and physics [1]. There are two main branches in biology, functional biology and evolutionary biology. The former deals with the physiology of living beings and is believed to be based almost entirely on physics and chemistry, the latter, on the other hand, deals-to a large extent-with unique phenomena that occur within a certain time frame.

Physical laws explain in increasing detail how atoms are constructed and behave. Molecular biology explains the processes in an organism on the basis of biochemical reactions. Through the deep understanding of physics and the observation of celestial bodies and astronomical phenomena, significant insight into the history and functioning 
of the universe has been gained. Likewise, through the growing knowledge of molecular biology and the study of living beings and fossils, deep insight into the evolution of life has been acquired.

Surely it can be argued that physics explains chemistry, and thereby molecular biology; however; a physicist will soon notice that the reductionism inherent to physics can prevent one from recognizing important relationships underlying seemingly chaotic events, from appreciating evolutionary origins, and from perceiving the heterogeneity of complex systems, which is at the very essence of the study of biology. The success of reductionism in physics is that the concept of classes whose members are identical applies superbly to the inanimate world. In the study of the animate world, we deal with populations in which, by contrast, each individual is unique. These populations' characteristics further change gradually from generation to generation and do not differ from each other by their nature, but only by statistical averages. In biological sciences, we therefore often encounter a holism that can, on the contrary, complicate recognizing fundamental principles within complex systems.

Therefore, while physics and molecular biology explain how the animate and inanimate worlds work, and astrophysics and evolutionary biology teach us the history of both, only together can they provide the bigger picture. The living world conveys the concept of eternally variable objects of study, grading into each other from generation to generation, whereas the immutable laws of physics predispose a typologist's view. These two fundamentally different approaches colliding shows the importance of approaching the fundamental questions of the future and purpose of life and the universe in an interdisciplinary and unifying way, since neither of them can be accomplished independently [2].

\subsection{The Origin and Provision of the Elements}

All known forms of life require a certain set of chemical elements for biochemical functioning. These core elements are the building blocks for carbohydrates, nucleic acids, proteins, and lipids, the four categories of molecules that make up the structure and function of organic life. It is thought that quarks and electrons formed when the universe started to cool after the Big Bang. Quarks aggregated to form protons, as well as neutrons, which, in turn, combined to form nuclei. Upon further cooling, electrons intertwined in orbits around these nuclei to form the first atoms, mainly hydrogen and helium, by far the most abundant elements in the universe [3-5]. Gas clouds of these then formed the first generation of stars, which includes the most massive ones. Since a star's lifetime is inversely proportional to its mass cubed, these stars would have been relatively short-lived. Within these stars, hydrogen and helium were fused into heavier and heavier elements and expelled into the interstellar medium during their burst, enriching it with the remaining chemical elements required for life [6-9].

Stars that formed subsequently would not be exclusively composed of hydrogen and helium, which would prevent them from growing as massive and thereby prolong their lifetime. In fact, some are still visible today. Others, instead, exploded, and allowed later generations of stars, such as the Sun, to be richer still in heavier elements [10,11].

Within our solar system, planets are believed to have formed by collision and selforganization from the gas and dust that was left by a fraction of the giant molecular cloud that formed the Sun. At greater distance from the Sun, where volatile molecules such as water and methane remained icy, and hence solid, respectively large planets could form. Closer to the Sun, planets like Earth could only form from less prevalent compounds with high melting points, such as metals and rocky silicates, and therefore remained comparatively small $[12,13]$.

Due to frequent collisions with other bodies and extreme volcanism, the Earth was initially molten. With time, the outer layer of the planet cooled and formed a solid crust [14,15]. When and how oceans of liquid water appeared on planet Earth is not yet entirely resolved, but, as we will see, it is on the bottom of these that life on Earth has its most likely origins. The habitability boundary could be as early as $4.5 \mathrm{Ga}$, representing the earliest possible 
estimate of the time at which the Earth had a stable crust and hydrosphere, or as late as $3.9 \mathrm{Ga}$, the end of the period of heavy meteorite bombardment [16,17].

\subsection{The Birth of Life}

A central unifying concept in biology, known as cell theory, recognizes the cell as the basic unit of life [18]. Living beings, which are composed of one or more cells, are thermodynamically open systems that achieve homeostasis by reducing entropy through the use of energy. Additionally, according to cell theory, cells arise by division from pre-existing cells, which leaves the question of the origin of the first cell unanswered.

Abiogenesis defines the yet unknown process though which life arose from matter, and while the details are in some debate, it is mostly agreed upon to not be a single event, but rather a process of increasing complexity that involves molecules capable of self-assembly and self-reproduction [19-24]. Ribonucleic acid (RNA) macromolecules best match this profile, but the formation of such in the first place and the path from these polymers to the first membrane-enclosed cell would still yet needs to be elucidated. The mechanisms by which mutual catalysis in a pre-biotic network could lead to a proto-metabolic network have been described $[25,26]$, and suggest that many features of life as we know it today, such as homochirality and template-directed replication, arose even before this RNA world.

The first step from matter to life is the formation of organic molecules; these can form from inorganic molecules in certain environments under certain conditions [27-29]. Early Earth's atmosphere provided the required ingredients, and hydrothermal vents have been described as one potential source of organic compounds [30-34].

The theory of evolution is based on the idea that all species are related and gradually change over time due to genetic variation affecting an organism's phenotype and natural selection [35], and, hence, postulates a last universal common ancestor for all currently living beings, LUCA. LUCA is hypothesized to have been a hyperthermophilic single-celled organism with a lipid bilayer membrane and a circular DNA chromosome. It encoded the standard machinery for replicating its chromosome and translating genes. It is believed to have inhabited anaerobic hydrothermal vents in a hydrogen-, carbon dioxide-, and iron-enriched atmosphere [36-39].

Evolution had gone a long way from abiogenesis to LUCA, and even though it is considered to be far less complex than any organism living today, tangibly envisioning the genesis of life from matter reaching to such vast complexity currently seems beyond reach.

The first living organism in an otherwise abiotic world would, by definition, be assumed to be an autotroph, capable of fixating carbon. Being the last universal common ancestor for all currently living beings is not the same as being the first living being on Earth. Nevertheless, LUCA seemed capable of using hydrogen to reduce carbon dioxide to carbon monoxide and formic acid; it actually seemed to build its entire metabolism on carbon fixation from carbon dioxide and hydrogen via the reductive acetyl CoA pathway, which indicates a not too distant relationship with the first living being [36,40-42].

The tree of life begins with LUCA and splits into the two main domains from there, the Bacteria domain and the Archaea domain [43-46]. The first bacteria are believed to have been the clostridia, and the first archaea the methanogens, both sharing many properties with LUCA [47]. Organisms living during this time, which is believed to be the early Precambrian, where the Earth's surface had just started to cool down and its atmosphere consisted, in large part, of nitrogen, hydrogen, carbon dioxide, and methane, relied on a strictly anaerobic biochemistry. Many of the enzymes employed by these organisms are believed to have been metalloproteins [48], imposing the requirement for certain heavy metals and, hence, linking the early stages of the origin of life to the geophysical and geochemical conditions of the early Earth [49].

To summarize, hydrogen formed in the Big Bang, and most other elements later on in the demise of stars and similar events. Organic compounds have several potential sources, of which deep hydrothermal vents on Earth are one. All life forms known to date can 
be traced to one common single-celled ancestor that displayed features suggesting such a habitat.

The Sun is a star, of which there are countless many. Earth-like planets have been hypothesized and are now being described more and more often. Nevertheless, to date, there is no evidence pointing to the fact that abiogenesis has occurred more than once in the history of the universe, for the time being until further notice, elevating the uniqueness of this event to that of the Big Bang. Understanding how life formed could tremendously advance understanding of its nature and purpose; likewise, understanding its nature and purpose could tremendously advance our understanding of its origin. Genetics is what has allowed us to go so far back and reconstruct the theoretical construct of LUCA. Unluckily, the fact that we currently still lack knowledge regarding the events that led from complex organic compounds to LUCA is due to the fact that, with this method, we can only go back to cells that already had genetics. Nevertheless, based on the gathered evidence, we apprehend that the oldest known cell is an already complex machinery that has its construction manual and work instructions written in the form of complex organic molecules (DNA).

The key point here is that LUCA's genetic code depends on machinery (contrary to the genetic code of self-replicating RNA molecules) that contains all the necessary information on how to build the tools (mostly enzymes) to ensure that the tools are built and that the code is copied. For this machinery to work, the tools that read and build (called ribosomes) need to already be built and carried along. Ribosomes are largely composed of RNA and are hypothesized to have been fully composed of it during early life on Earth [50-52]. Since RNA also has DNA-like properties, it is believed that the instruction manual (DNA) and the tool that reads and builds according to it (ribosomes) have a common precursor molecule. Selection itself has been described under certain circumstances to lead to replicators grouping themselves together in ways that favor cooperation and synergy [53], suggesting that the fittest is a cooperative and dynamic unit [54].

RNA molecules can fold into complex three-dimensional structures but are composed of a one-dimensional matrix that contains mostly no more than a few thousand characters that are furthermore limited to four variables. The potential first self-replicating molecule could, hence, be experimentally determined and reproduced. It should be noted that environmental conditions could have influenced the folding pattern. Therefore, computer simulations might prove even more useful than laboratory experiments in regard to finding a candidate.

Viruses appear to have been present during these early stages in the origin of life, making it conceivable that the first replicating nucleic acids were independent of life but contributed to it. Genetic parasites, such as viruses, plasmids, and transposons, might have started out as cooperative commensals or symbionts and only later evolved into elaborate selfish agents [55].

Life as we know it originated under highly unique, specific, and contained conditions and then grew in complexity, which, in turn, allowed it to expand to and prosper in environments in which it could not have been originated anew, like a spark that ignites a blaze. The discovery of the aforementioned hypothesized first self-replicating molecule, however, could really portray life as little but a complex physical system, anything but unique, and abiogenesis as an expected consequence of the physical laws.

\subsection{Heterotrophy}

While autotrophic organisms are capable of converting inorganic carbon dioxide to organic carbon compounds, heterotrophs cannot, and instead derive their energy from organic carbon compounds fabricated by others. High-hydrogen environments such as hydrothermal vents thermodynamically favor the synthesis of organics, whereas lower concentrations of hydrogen make the fermentation of these more favorable [56,57]. The first heterotrophic organisms seem to have evolved at sufficient distance from hydrothermal 
vents or in ones that were no longer active, living on the cell sediments of autotrophs. Viruses present during these early stages of life could have further contributed free organic compounds by inducing cell lysis [54,57]. Ribose is thought to have been the first abundant sugar [40]. Most of the machinery for the fermentation of organic compounds was already in place in autotrophs, enabling amino acid and purine fermentation. Hence, heterotrophy was a conceivably suggestive evolutionary development in living cells and an opportunity for life to prosper in these environments.

\subsection{Photosynthesis: The Implications of Innovation}

The next big leap was the evolution of pigments that were capable of being excited by light at certain wavelengths and thereby converting and storing light energy as chemical energy. The ozone layer not yet being formed, light at long wavelengths was mainly used [58,59]. This early form of photosynthesis was presumably anoxygenic [60-63]. It reduced agents other than water-namely, first hydrogen, then sulfur, and then iron-and therefore did not produce oxygen. These organisms were descendants of the first bacteria and must presumably had already left the vicinity of the hydrothermal vents to inhabit light-accessible ocean layers.

Over hundreds of millions of years, their descendants, in turn, evolved, on the one hand, a photosynthetic apparatus that reduced water and produced oxygen, and, on the other hand, systems of protection against the destructive effect of this very product $[64,65]$. The ability to use water for reduction, an almost unlimited resource, led to the explosive proliferation of these organisms. These inconspicuous, minute new tools allowed these organisms, which were ancestors of today's known cyanobacteria, to bloom and shape this planet that we know as Earth in an unparalleled and unprecedented way. The growing abundance of thereby produced oxygen first reacted with minerals by approximately $2.8 \mathrm{Ga}$, and once these were saturated, half a billion years later, accumulated in the atmosphere and depleted it of methane [60]. The results were manifold, from further planetary cooling due to a markedly weakened greenhouse effect to a mass extinction of anaerobic organisms that were exposed to but not suited to this new environment and probably constituted the larger part of life to date [66-68].

Anoxygenic photosynthesis provided an alternative energy source, but oxygenic photosynthesis provided a novel way of life. Independence from the limited resources of geochemically derived reductants enabled these cells to conquer completely new habitats and displaced differently evolved contemporaries into niches. An organism that is not appropriately geared to keep cellular functions running in the environment in which it is located has to change environment, gear up, or survive until the environment is more favorable. Anything else likely results in the living organism irreversibly disintegrating to more- and less-complex organic molecules. The mass proliferation of cyanobacterial precursors and the mass extinction of anaerobes suggest that the ultimate agenda of these unicellular organisms was to thrive and reproduce, if possible, no ifs and buts, as a consequence of the fact that the biochemical processes of these machineries did not amount to anything else.

\subsection{Eukaryotes: Symbiosis and Predation}

Approximately halfway through the Precambrian, the first highly complex unicellular organisms appear-Eukaryotes $[69,70]$. These cells were significantly larger than their ancestors and had a highly organized internal structure. Their high energy demand was satisfied by an entirely new evolutionary accomplishment: a cellular organelle completely dedicated to generating energy at peak efficiency through oxygen combustion.

This organelle is hypothesized to have had been a small single-celled organism by itself that ended up inside another, larger, single-celled organism [71]; a relationship that turned out to have mutual benefits and resulted in the larger cell not only hosting the smaller one, but, with time, even encoding its genome. Two organisms had merged to form one [72-75]. 
Predation is assumed to have had a large role in shaping evolution, to have arisen relatively early, and is even thought of as one possible mechanism by which mitochondrial precursors entered their host $[76,77]$. The key point is the fact that, although predation might have shaped evolution again and again, as we will later see, the winning strategy here is cooperation. Additionally, we can term it "winning", given the subsequent evolutionary success of eukaryotic organisms, defining success as comprising a significant number of the organisms and the amount of biomass to this very date.

The idea that an organism is actually composed of two organisms can be troubling to a human mind. In science and philosophy, this key issue has hence been addressed in several ways [78-80].

The acquisitions of highly organized internal organization and a mitochondrial powerhouse enabled unique new thriving opportunities, among which, preying on much smaller prokaryotic contemporaries was just one. The real breakthrough for eukaryotic cells, however, was the evolution of multicellularity. Thereby, their actual potential was tapped.

\subsection{Multicellularity: Challenging Concepts}

The main disadvantage of being a large eukaryotic cell, as compared to a small bacterial or archaeal one, is the lower surface-to-volume ratio and the resulting difficulty in absorbing and transporting nutrients through the cell. Multicellularity, as we will see, remedies this problem while preserving the competitive advantages of increased cell size.

Precursors to multicellularity are thought to be multicellular colonies [81,82]. In these, increasing cell specialization then led to the transition from colonial aggregates to truly multicellular organisms. Unlike abiogenesis and the evolution of eukaryotes, the step to multicellularity seems not to have been a one-time event, but to have occurred independently several times in various species [83-86]. The main mechanism that allowed for multicellularity was adhesion. These organisms did not have to reinvent the wheel. Mechanisms that were used to adhere to surfaces just had to be used to instead adhere to other cells. These organisms' multicellularity was, however, limited to two-dimensional structures in which every participating cell was exposed to the environment, their main source of nutrient supply.

Somewhat more singular was the step to complex multicellularity, which was based not only on cells of an organism sticking together, but also on them additionally exchanging nutrients and signal molecules, which was necessary for their novel three-dimensional organization in which only some of the cells remained in direct contact with the environment $[86,87]$. Interpreting this evolutionary step as a success would not be based on metazoan bias, but on the realization that complex multicellularity significantly better harnessed the potential of eukaryotic cells over bacterial and archaeal ones. In the end, it is always the biological framework that determines the winning strategy.

The emergence of complex multicellularity was an important transition in evolution, and is generally thought to be associated with increased genomic complexity $[83,86,88]$. Unicellular life is relatively simple because there is little division of labor, resulting in the genetic information content of single-celled organisms being comparatively low. Multicellular life, on the other hand, requires more genetic information because significantly more cellular functions must be accomplished; cells differentiate into different cell types, tissues, and organs, but each cell contains the blueprint of the organism as a whole. Additionally multicellular organisms need a master developmental program, a way to direct specific cells to take on specialized jobs in different parts of the body. This master developmental program is a so-called "Hox gene cluster", and is responsible for the diversification of body plans, ensuring that the correct structures form in the correct places in the body [89,90].

The key to the success of the symbiosis between mitochondrial precursors and their host cell was that both had different characteristics that complemented each other in a fruitful way. Today, we think of a good team as one in which each member can rely on each other member to deal with the respective task allotted to them. Additionally, as teamwork has proven itself to be a successful strategy in the history of society, so it also has in the 
history of evolution. Complex multicellularity follows the same principle, that of teamwork and labor division. Different cells take up different functions in the organism. Later in evolution, this organization would further escalate to a whole new level by producing tissues and organs within organisms.

Complex multicellularity led to what appears to be a relatively explosive development and differentiation of organisms, many of which were fossilized and therefore allow us some clarity today. The degree of explosiveness of the event is debated but not relevant to our purpose. Relevant to our purpose instead is another concept: even though, up to now, we could think of an organism as something enclosed within and limited by a cell-wall, the concept of an organism can go beyond that. We now have to start thinking of an organism as something that can also be composed of many individual cells. We could abandon the thought that an organism's outermost borders are necessarily cell walls, and rather try to think of an organism as the macromolecular complex that self-replicates, which includes both its DNA and its machinery. Such a definition also expands the status of an organism to hypothetical self-replicating RNA-molecules without a membrane.

Cell theory recognizes the cell as the basic unit of life [18], among others, because, for a human mind, thinking of a unit as something whose ends are unmistakably demarcated and spatially separated from another unit or its outside is eminently conceivable. We see, however, how drastically this oversimplification can distort our understanding of what life might actually be.

The fact that complex multicellular organisms are composed of differently differentiated cells that have different fates, and that some of these lose their ability to self-replicate, implies a tremendously complex concept of what the basic unit of life is, and even challenges our very capability to define it. It is even more intricate due to the fact that these self-replicating complexes are designed to suffer alterations every few replications and thereby cannot really be termed "self-replicating" either. One viewpoint suggests that shifting emphasis to the origins of computation, control, and informational architecture, rather than focusing solely on Darwinian evolution, allows for a more universal view of life, where the same underlying principles enable insight into living systems instantiated in different substrates elsewhere [91].

Here, we understand the complexity of matters discussed in the philosophy of biology, and leave addressing these for now, for our purpose in this work is limited to enlightening the path that has empowered us to do so.

\subsection{Room for Sensation}

Being part of an organism in which one group of cells takes care of nutrient supply for all and another group manages the remaining life-saving tasks gave all other cells the possibility to find utterly novel purposes that might prove valuable. In fact, this point in time, known as the "Cambrian explosion", is characterized by tremendous evolutionary inventiveness [92,93].

While limbs and shells certainly seem resourceful inventions, we will focus on the novelty that has turned out to be the most significant in our context, and perhaps as a whole: the neural network. Neurons are electrically excitable cells with the ability and purpose of transmitting signals from one end to another. Taken by itself, this is no great accomplishment; in fact, it is when many neurons are connected to form a network or neuronal circuit that their full potential is attained. Nervous systems enable organisms to receive sensory information from their external and internal environment, process this information, and regulate neurosecretory and motor systems. To operate such tasks, at least three types of neurons are required.

Afferent or sensory neurons are those receptive to stimuli. These stimuli can be internal or external. A sensory neuron is the first link in the signal chain of a sensory organ. In most cases, it is designed for specific types of stimuli. The evolutionary earliest receptor cells were probably designed for chemical, thermal, mechanical, or electrical stimuli [94]. 
In these sensory cells, these stimuli alter a receptive cellular structure in a particular way, thus generating and transmitting a neuronal signal.

Efferent neurons are those that are stimulated by other neurons and eventually carry a signal to a target effector.

Interneurons, instead, the third type of neurons, are the most interesting ones. These compose neural circuits, conducting the flow of signals between a sensory neuron and a motor neuron. Interneurons can be arranged in functional chains and perform complex functions through interactions with each other. In more complex multicellular organisms, the network of interneurons can be sufficiently complex to allow for the processing and interpretation of a signal. Even different sensory information can be integrated.

Single-celled organisms were already capable of responding sensibly to stimuli in their environment by sensing food sources or toxins through special receptor molecules in the cell wall $[95,96]$. When these simple receptor structures were stimulated, they caused the prokaryote to move in a more favorable direction, such as towards food or away from danger. Even electrical signaling between cells started well before neurons [97], but it was neurons that made signaling efficient in complex multicellular organisms.

The first neurons are believed to have had sensory and effector functions, hence, interneurons have evolutionarily followed only subsequently. In the course of evolution, and with the higher development of individual divisions in the animal kingdom, a clear tendency toward the concentration and concomitant specialization of parts of the nervous system can be observed. While seemingly diffuse networks of interneurons were the rule at first, in some more complex organisms, organized groups of neurons began to appear, forming what can best be defined as a central nervous system. This made it possible to process information, rather than to just transmit it, and enabled these organisms to move and respond to their environment in increasingly sophisticated ways [98-100].

\subsection{The Human Brain}

In the same way in which not all prokaryotes switched to photosynthesis, and not all single-celled organisms took the path of symbiosis and/or multicellularity, not all multicellular organisms invested in neuronal development, and even those who did developed quite differing nervous systems. Evolutionarily conserved regions common to most, if not all brains, however, are those in charge of sustaining fundamental homeostatic functions [101]. Guided by our anthropocentric perspective we will focus on the development of the human brain.

The central nervous system started as a tube-like structure, given its origin in wormshaped complex multicellular organisms [102]. Its evolutionary path to becoming a human brain, which just represented one of many, started with an expansion of the central nervous system at the foremost end of the body, called the forebrain. Two other centers also originated from expansion just behind the former - the midbrain and the hindbrain. From the hindbrain, to which the spinal cord connects, the cerebellum developed. The forebrain was originally in charge of smelling, the midbrain was in charge of processing the information it received from the eyes, and the hindbrain controlled movement and spatial orientation [103-105].

While more posterior parts of the brain were in charge of life-support functions, evolutionary changes occurred primarily in the forebrain, which is used to make decisions and evaluate information. Higher performance, the ability to perform complex actions, and a willingness to learn are due to the enlargement of the outer layer of the forebrain, the cerebral cortex. In order for the ever-increasing surface area of the outer layer of nerves to still fit into the vertebrate skull, there was a continuous surface-increasing unfolding of the cortex [106]. The evolutionarily youngest part of the cerebral cortex is the neocortex, which is only found in mammals. It is particularly pronounced in humans and is the site of higher functions and cognitive abilities. It consists of sensory areas, areas which control voluntary movements and that link sensory impressions with corresponding emotions and behavioral patterns [107-109]. 
The highly valued ability to think, for example, is, with certainty, not exclusive to humans $[110,111]$; however, humans are a stone's throw ahead of their contemporaries in this respect. Which influences underlie the biological changes that caused the human brain to evolve in the way it has are highly debated issues. Nevertheless, it is not difficult to understand that complex reasoning, inventiveness, and advanced comprehension have been highly valuable tools that have allowed humans to survive, prosper, and dominate.

\subsection{Implications for Knowledge Emergence}

The only ways through which information conventionally reaches the human brain are the sensory nerve cells. The artificial direct stimulation of interneurons with complex tools available today, bypassing afferent cells, is imaginable, but by no means conventional. Our knowledge of the world within us and around us has thus always relied on these aforementioned cells. We refer to knowledge here as the totality of information and convictions we hold. Conversely, it has been proven that our brain acts on the selectivity of our perception [112-115], which leaves us with a fundamental issue: the only channel through which we receive information has a permeability in of that is modulated by the brain's interpretation of that very same information. Hence, further incoming information to be interpreted is probably already selected, eventually modified, and, hence, probably not absolute.

\subsection{Evolution: Patterns and the Question of Directionality}

Evolution resembles a probabilistic system [116,117]. Traits that give an organism a better chance to reproduce or survive and that can be passed on to offspring become more dominant over time. Traits that do the opposite dwindle over time as unsuited organisms die out or are displaced by better adapted ones. However, there are parameters that influence the characteristics of evolution $[118,119]$. The question of directionality in the biological history of the Earth therefore depends very much on the nature of the evolutionary scenario in which we actually find ourselves, which may vary in time. In a sparsely populated and newly claimed environment, organisms may not yet be at their optimum fitness, and evolution might appear to have directionality, selecting for more optimal fitness over time.

Species are constantly dying out as the environment changes, as organisms compete for environmental niches, and as genetic mutations cause older species to give rise to new ones. Occasionally, Earth's biodiversity suffers a blow in the form of major extinction events, which are an accumulation of smaller extinction events that occur in a relatively short period of time. Each of the five major extinction events that have occurred on Earth was characterized by up to $80 \%$ or more of the then currently living species being lost. However, life on Earth has always recovered, and dominance over certain ecological niches simply passed from one group of organisms to another [120-123].

Biodiversity is a measure of variation at the genetic, species, and ecosystem level. With mass-extinction events, global biodiversity has experienced some setbacks, but has gained significantly over the long term [124,125]. The period since the emergence of humans shows a continuous decline in biodiversity and a concomitant loss of genetic diversity. The reduction is mainly caused by human impacts, especially habitat destruction, and is even referred to as the sixth mass extinction [126,127]. The recent era of human influence on the environment reflects multiple geologic changes of global proportions. Our demands for resources and food, necessitating invasive mining and agricultural practices, have altered the surface of the planet today almost everywhere, and represent permanent geologic signatures that are global and form a boundary that is readily apparent in surface geology [128]. Like cyanobacteria and later terrestrial plants, we humans have shaped this planet to such a degree that the change is visible from the Moon. This alone speaks to the fact that human mental capabilities are an evolutionary breakthrough, the implications of which are rigorous, but whose extent can hardly be envisioned and should not be underestimated [129]. No matter whether mass extinctions were initiated due to 
evolutionary breakthroughs or through environmental phenomena, the long-term outcome so far has always been that of a recovery, an increasing biodiversity, and an overall tendency towards the emergence of more complex organisms.

\section{Conclusions}

Given that our human brain carefully selects the information it receives for processing, mostly without us being aware, our understanding of the universe, both near to and distant from us, is customized to our biological predisposition. The brain that guides us is one shaped by evolution, and evolution rewards those that are best suited for survival. The evolutionary breakthrough of this highly complex neuron network was that it allowed us to understand and use our environment so distinctively better than any other contemporary evolutionary novelty that we prospered, overpowering everything that was in our way. The brilliance of the human mind, therefore, must always be considered in the light of it being optimized for grasping things that ensure our survival and reproduction. The very laws of evolution might never even favor the formation of a mind optimized to understand the complexity of the universe that created it; excluding the latter ensures the survival and reproduction of the bearer. A future, instead, in which organisms might have at least a more profound understanding of the cosmos than humans to date is thinkable, with further increasing neuronal complexity or through a novel evolutionary means for example.

Philosophical questions that have troubled humankind since the dawn of time, such as the purpose of life in the universe, could still be around for the fact that neuronal networks optimized for philosophical problem solving have never given the bearer any advantages in fitness over their contemporaries, or even worse. In that case, we can hope that society might provide the required selective pressure or might at least allow a niche for such development.

Funding: This research received no external funding.

Institutional Review Board Statement: Not applicable.

Informed Consent Statement: Not applicable.

Acknowledgments: In particular, I would like to thank my infinitely supportive colleague and friend Christian Buechler, without whom this gratifying endeavor would not have been possible. Thank you.

Conflicts of Interest: The author declares no conflict of interest.

\section{References}

1. Walker, S.I. Origins of life: A problem for physics, a key issues review. Rep. Prog. Phys. 2017, 80, 092601. [CrossRef]

2. $\quad$ Preiner, M.; Asche, S.; Becker, S.; Betts, H.C.; Boniface, A.; Camprubi, E.; Chandru, K.; Erastova, V.; Garg, S.G.; Khawaja, N.; et al. The future of origin of life research: Bridging decades-old divisions. Life 2020, 10, 20. [CrossRef] [PubMed]

3. Puy, D.; Signore, M. From nuclei to atoms and molecules: The chemical history of the early Universe. New Astron. Rev. 2002, 46, 709-723. [CrossRef]

4. Allday, J. Quarks, Leptons and the Big Bang; CRC Press: Boca Raton, FL, USA, 2016.

5. Weisskopf, V. The Origin of the Universe. Bull. Am. Acad. Arts Sci. 1989, 42, 22. [CrossRef]

6. Bromm, V. Formation of the first stars. Rep. Prog. Phys. 2013, 76, 112901. [CrossRef]

7. Susa, H. The mass of the first stars. Astrophys. J. 2013, 773, 185. [CrossRef]

8. Iwamoto, N.; Umeda, H.; Tominaga, N.; Nomoto, K.; Maeda, K. The First Chemical Enrichment in the Universe and the Formation of Hyper Metal-Poor Stars. Science 2005, 309, 451-453. [CrossRef]

9. Pei, Y.C.; Fall, M.; Hauser, M.G. Cosmic histories of stars, gas, heavy elements, and dust in galaxies. Astrophys. J. 1999, 522, 604-626. [CrossRef]

10. Hartwig, T.; Yoshida, N.; Magg, M.; Frebel, A.; O Glover, S.C.; A Gómez, F.; Griffen, B.; Ishigaki, M.N.; Ji, A.P.; Klessen, R.S.; et al. Descendants of the first stars: The distinct chemical signature of second-generation stars. Mon. Not. R. Astron. Soc. 2018, 478, 1795-1810. [CrossRef]

11. Smith, B.D.; Sigurdsson, S. The transition from the first stars to the second stars in the early universe. Astrophys. J. 2007, 661, L5-L8. [CrossRef]

12. Montmerle, T.; Augereau, J.-C.; Chaussidon, M.; Gounelle, M.; Marty, B.; Morbidelli, A. Solar system formation and early evolution: The first 100 million years. Earth Moon Planets 2006, 98, 39-95. [CrossRef] 
13. Lissauer, J.J. Planet formation. Annu. Rev. Astron. Astrophys. 1993, 31, 129-172. [CrossRef]

14. Yin, Q.; Jacobsen, S.B.; Yamashita, K.; Blichert-Toft, J.; Telouk, P.; Albarede, F. A short timescale for terrestrial planet formation from Hf-W chronometry of meteorites. Nat. Cell Biol. 2002, 418, 949-952. [CrossRef]

15. Wetherill, G.W. Formation of the Earth. Annu. Rev. Earth Planet. Sci. 1990, 18, 205-256. [CrossRef]

16. Benner, S.A.; Bell, E.A.; Biondi, E.; Brasser, R.; Carell, T.; Kim, H.J.; Trail, D. When did life likely emerge on Earth in an RNA-first process? arXiv 2019, arXiv:1908.11327.

17. Pearce, B.K.; Tupper, A.S.; Pudritz, R.E.; Higgs, P.G. Constraining the time interval for the origin of life on earth. Astrobiology 2018, 18, 343-364. [CrossRef]

18. Mazzarello, P. A unifying concept: The history of cell theory. Nat. Cell Biol. 1999, 1, E13-E15. [CrossRef]

19. Pross, A.; Pascal, R. The origin of life: What we know, what we can know and what we will never know. Open Biol. 2013, 3, 120190. [CrossRef]

20. Mulkidjanian, A.Y.; Galperin, M.Y. Physico-chemical and evolutionary constraints for the formation and selection of first biopolymers: Towards the consensus paradigm of the abiogenic origin of life. Chem. Biodivers. 2007, 4, 2003-2015. [CrossRef]

21. Orgel, L.E. The origin of life-A review of facts and speculations. Trends Biochem. Sci. 1998, 23, 491-495. [CrossRef]

22. Küppers, B.-O. Information and the Origin of Life; Mit Press: Cambridge, MA, USA, 1990.

23. Gilbert, W. Origin of life: The RNA world. Nat. Cell Biol. 1986, 319, 618. [CrossRef]

24. Oparin, A. The Origin of Life on the Earth; Oliver \& Boyd: Edinburgh, UK; Oliver \& Boyd: London, UK, 1957.

25. Copley, S.D.; Smith, E.; Morowitz, H.J. The origin of the RNA world: Co-evolution of genes and metabolism. Bioorganic Chem. 2007, 35, 430-443. [CrossRef]

26. Copley, S.D.; Smith, E.; Morowitz, H.J. A mechanism for the association of amino acids with their codons and the origin of the genetic code. Proc. Natl. Acad. Sci. USA 2005, 102, 4442-4447. [CrossRef] [PubMed]

27. Vastel, C.; Ceccarelli, C.; Lefloch, B.; Bachiller, R. The origin of complex organic molecules in prestellar cores. Astrophys. J. 2014, 795, L2. [CrossRef]

28. Podlech, J. Origin of organic molecules and biomolecular homochirality. Cell. Mol. Life Sci. 2001, 58, 44-60. [CrossRef] [PubMed]

29. Chyba, C.; Sagan, C. Endogenous production, exogenous delivery and impact-shock synthesis of organic molecules: An inventory for the origins of life. Nat. Cell Biol. 1992, 355, 125-132. [CrossRef]

30. Colín-García, M. Hydrothermal vents and prebiotic chemistry: A review. Boletín Soc. Geológica Mex. 2016, 68, 599-620. [CrossRef]

31. Konn, C.; Charlou, J.-L.; Holm, N.G.; Mousis, O. The production of methane, hydrogen, and organic compounds in ultramafichosted hydrothermal vents of the Mid-Atlantic ridge. Astrobiology 2015, 15, 381-399. [CrossRef]

32. Lang, S.Q.; Butterfield, D.A.; Schulte, M.; Kelley, D.S.; Lilley, M.D. Elevated concentrations of formate, acetate and dissolved organic carbon found at the Lost City hydrothermal field. Geochim. Cosmochim. Acta 2010, 74, 941-952. [CrossRef]

33. Martin, W.; Baross, J.; Kelley, D.; Russell, M.J. Hydrothermal vents and the origin of life. Nat. Rev. Genet. 2008, 6, 805-814. [CrossRef]

34. Van Dover, C. The ecology of Deep-Sea Hydrothermal Vents; Princeton University Press: Princeton, NJ, USA, 2000.

35. Smith, J.M. The Theory of Evolution; Cambridge University Press: Cambridge, UK, 1993.

36. Weiss, M.C.; Sousa, F.L.; Mrnjavac, N.; Neukirchen, S.; Roettger, M.; Nelson-Sathi, S.; Martin, W.F. The physiology and habitat of the last universal common ancestor. Nat. Microbiol. 2016, 1, 16116. [CrossRef]

37. Glansdorff, N.; Xu, Y.; Labedan, B. The last universal common ancestor: Emergence, constitution and genetic legacy of an elusive forerunner. Biol. Direct 2008, 3, 29. [CrossRef]

38. Koonin, E.V. Comparative genomics, minimal gene-sets and the last universal common ancestor. Nat. Rev. Genet. 2003, 1, 127-136. [CrossRef]

39. Penny, D.; Poole, A. The nature of the last universal common ancestor. Curr. Opin. Genet. Dev. 1999, 9, 672-677. [CrossRef]

40. Schönheit, P.; Buckel, W.; Martin, W.F. On the origin of heterotrophy. Trends Microbiol. 2016, 24, 12-25. [CrossRef] [PubMed]

41. Lane, N.; Martin, W.F. The origin of membrane bioenergetics. Cell 2012, 151, 1406-1416. [CrossRef] [PubMed]

42. Martin, W.; Russell, M.J. On the origins of cells: A hypothesis for the evolutionary transitions from abiotic geochemistry to chemoautotrophic prokaryotes, and from prokaryotes to nucleated cells. Philos. Trans. R. Soc. B Biol. Sci. 2003, $358,59-85$. [CrossRef] [PubMed]

43. Schleper, C.; Sousa, F.L. Meet the relatives of our cellular ancestor. Nat. Cell Biol. 2020, 577, 478-479. [CrossRef] [PubMed]

44. Williams, T.A.; Cox, C.J.; Foster, P.G.; Szöllősi, G.J.; Embley, T.M. Phylogenomics provides robust support for a two-domains tree of life. Nat. Ecol. Evol. 2020, 4, 138-147. [CrossRef]

45. Eme, L.; Spang, A.; Lombard, J.; Stairs, C.W.; Ettema, T.J.G. Archaea and the origin of eukaryotes. Nat. Rev. Genet. 2017, 15, 711-723. [CrossRef]

46. Spang, A.; Saw, J.H.; Jørgensen, S.L.; Zaremba-Niedzwiedzka, K.; Martijn, J.; Lind, A.E.; Van Eijk, R.; Schleper, C.; Guy, L.; Ettema, T.J.G. Complex archaea that bridge the gap between prokaryotes and eukaryotes. Nat. Cell Biol. 2015, 521, 173-179. [CrossRef] [PubMed]

47. Martin, W.F.; Sousa, F.L. Early microbial evolution: The age of anaerobes. Cold Spring Harb. Perspect. Biol. 2015,8 , a018127. [CrossRef] [PubMed]

48. Martin, W.F. Hydrogen, metals, bifurcating electrons, and proton gradients: The early evolution of biological energy conservation. FEBS Lett. 2011, 586, 485-493. [CrossRef] 
49. Cody, G.D.; Scott, J.H.; Sullivan, I.W.T.; Baross, J. The roots of metabolism. In Planets and Life; Cambridge University Press: Cambridge, UK, 2018; pp. 174-186.

50. Petrov, A.S.; Gulen, B.; Norris, A.M.; Kovacs, N.A.; Bernier, C.R.; Lanier, K.A.; Fox, G.E.; Harvey, S.C.; Wartell, R.M.; Hud, N.V.; et al. History of the ribosome and the origin of translation. Proc. Natl. Acad. Sci. USA 2015, 112, 15396-15401. [CrossRef] [PubMed]

51. Fox, G.E. Origin and evolution of the ribosome. Cold Spring Harb. Perspect. Biol. 2010, 2, a003483. [CrossRef] [PubMed]

52. Caetano-Anollés, G. Tracing the evolution of RNA structure in ribosomes. Nucleic Acids Res. 2002, 30, 2575-2587. [CrossRef]

53. Levin, S.R.; Gandon, S.; West, S.A. The social coevolution hypothesis for the origin of enzymatic cooperation. Nat. Ecol. Evol. 2019, 4, 132-137. [CrossRef]

54. Xavier, J.C. The early origin of cooperation. Nat. Ecol. Evol. 2019, 4, 18-19. [CrossRef]

55. Krupovic, M.; Dolja, V.V.; Koonin, E.V. Origin of viruses: Primordial replicators recruiting capsids from hosts. Nat. Rev. Genet. 2019, 17, 449-458. [CrossRef]

56. Preiner, M.; Xavier, J.C.; Vieira, A.D.N.; Kleinermanns, K.; Allen, J.F.; Martin, W.F. Catalysts, autocatalysis and the origin of metabolism. Interface Focus 2019, 9, 20190072. [CrossRef]

57. Lane, N.; Allen, J.F.; Martin, W. How did LUCA make a living? Chemiosmosis in the origin of life. BioEssays 2010, 32, 271-280. [CrossRef] [PubMed]

58. Fuhrman, J.A.; Caron, D.A. Heterotrophic planktonic microbes: Virus, bacteria, archaea, and protozoa. Available online: https:/ / dornsife.usc.edu/assets/sites/378/docs/Caron_pdfs/2016_FuhrmanCaron_MEM4thEd.pdf (accessed on 21 May 2021).

59. Martin, W.F.; A Bryant, D.; Beatty, J.T. A physiological perspective on the origin and evolution of photosynthesis. FEMS Microbiol. Rev. 2018, 42, 205-231. [CrossRef] [PubMed]

60. Blankenship, R.E. Early Evolution of photosynthesis. Plant Physiol. 2010, 154, 434-438. [CrossRef]

61. Olson, J.M. Photosynthesis in the Archean Era. Photosynth. Res. 2006, 88, 109-117. [CrossRef]

62. Blankenship, R.E. Origin and early evolution of photosynthesis. Photosynth. Res. 1992, 33, 91-111. [CrossRef]

63. Garlick, S.; Oren, A.; Padan, E. Occurrence of facultative anoxygenic photosynthesis among filamentous and unicellular cyanobacteria. J. Bacteriol. 1977, 129, 623-629. [CrossRef]

64. Fischer, W.W.; Hemp, J.; Johnson, J.E. Evolution of oxygenic photosynthesis. Annu. Rev. Earth Planet. Sci. 2016, 44, 647-683. [CrossRef]

65. Ward, L.M.; Kirschvink, J.L.; Fischer, W.W. Timescales of oxygenation following the evolution of oxygenic photosynthesis. Orig. Life Evol. Biosph. 2015, 46, 51-65. [CrossRef]

66. Och, L.M.; Shields-Zhou, G.A. The Neoproterozoic oxygenation event: Environmental perturbations and biogeochemical cycling. Earth-Science Rev. 2012, 110, 26-57. [CrossRef]

67. Shields-Zhou, G.; Och, L. The case for a neoproterozoic oxygenation event: Geochemical evidence and biological consequences. GSA Today 2011, 21, 4-11. [CrossRef]

68. Kopp, R.E.; Kirschvink, J.L.; Hilburn, I.A.; Nash, C.Z. The paleoproterozoic snowball Earth: A climate disaster triggered by the evolution of oxygenic photosynthesis. Proc. Natl. Acad. Sci. USA 2005, 102, 11131-11136. [CrossRef] [PubMed]

69. Zimmer, C. On the origin of eukaryotes. Science 2009, 325, 666-668. [CrossRef]

70. Roger, A.J.; A Hug, L. The origin and diversification of eukaryotes: Problems with molecular phylogenetics and molecular clock estimation. Philos. Trans. R. Soc. B Biol. Sci. 2006, 361, 1039-1054. [CrossRef]

71. Sagan, L. On the origin of mitosing cells. J. Theor. Biol. 1967, 14, 225-274. [CrossRef]

72. Cox, C.J.; Foster, P.G.; Hirt, R.P.; Harris, S.R.; Embley, T.M. The archaebacterial origin of eukaryotes. Proc. Natl. Acad. Sci. USA 2008, 105, 20356-20361. [CrossRef]

73. De Duve, C. The origin of eukaryotes: A reappraisal. Nat. Rev. Genet. 2007, 8, 395-403. [CrossRef] [PubMed]

74. Cavalier-Smith, T. The phagotrophic origin of eukaryotes and phylogenetic classification of protozoa. Int. J. Syst. Evol. Microbiol. 2002, 52, 297-354. [CrossRef]

75. Sogin, M.L. Early evolution and the origin of eukaryotes. Curr. Opin. Genet. Dev. 1991, 1, 457-463. [CrossRef]

76. Davidov, Y.; Jurkevitch, E. Predation between prokaryotes and the origin of eukaryotes. BioEssays 2009, 31, 748-757. [CrossRef]

77. Langerhans, R.B. Evolutionary consequences of predation: Avoidance, escape, reproduction, and diversification. In Predation in Organisms; Metzler, J.B., Ed.; Springer: Berlin/Heidelberg, Germany, 2007; pp. 177-220.

78. Booth, A. Symbiosis, selection, and individuality. Biol. Philos. 2014, 29, 657-673. [CrossRef]

79. Clarke, E. The Problem of Biological Individuality. Biol. Theory 2010, 5, 312-325. [CrossRef]

80. Lane, N. Power, Sex, Suicide: Mitochondria and the Meaning of Life; Oxford University Press: Oxford, UK, 2006.

81. Herron, M.D.; Borin, J.M.; Boswell, J.C.; Walker, J.; Chen, I.-C.K.; Knox, C.A.; Boyd, M.; Rosenzweig, F.; Ratcliff, W.C. De novo origins of multicellularity in response to predation. Sci. Rep. 2019, 9, 1-9. [CrossRef] [PubMed]

82. Libby, E.; Rainey, P.B. A conceptual framework for the evolutionary origins of multicellularity. Phys. Biol. 2013, 10, 035001. [CrossRef]

83. Niklas, K.J.; Cobb, E.D.; Dunker, A.K. The number of cell types, information content, and the evolution of complex multicellularity. Acta Soc. Bot. Pol. 2014, 83, 337-347. [CrossRef]

84. Ruiz-Trillo, I.; Burger, G.; Holland, P.W.; King, N.; Lang, B.F.; Roger, A.J.; Gray, M.W. The origins of multicellularity: A multi-taxon genome initiative. Trends Genet. 2007, 23, 113-118. [CrossRef] [PubMed]

85. Bonner, J.T. The origins of multicellularity. Integr. Biol. 1998, 1, 27-36. [CrossRef] 
86. Nagy, L.G. Evolution: Complex multicellular life with 5,500 genes. Curr. Biol. 2017, 27, R609-R612. [CrossRef] [PubMed]

87. Knoll, A.H. The multiple origins of complex multicellularity. Annu. Rev. Earth Planet. Sci. 2011, 39, 217-239. [CrossRef]

88. Lynch, M.; Conery, J.S. The origins of genome complexity. Science 2003, 302, 1401-1404. [CrossRef]

89. Lemons, D.; McGinnis, W. Genomic evolution of Hox gene clusters. Science 2006, 313, 1918-1922. [CrossRef] [PubMed]

90. Ruddle, F.H.; Bartels, J.L.; Bentley, K.L.; Kappen, C.; Murtha, M.T.; Pendleton, J.W. Evolution of hox genes. Annu. Rev. Genet. 1994, 28, 423-442. [CrossRef] [PubMed]

91. Walker, S.I. Top-down causation and the rise of information in the emergence of life. Information 2014, 5, 424-439. [CrossRef]

92. Lee, M.S.; Soubrier, J.; Edgecombe, G.D. Rates of phenotypic and genomic evolution during the cambrian explosion. Curr. Biol. 2013, 23, 1889-1895. [CrossRef] [PubMed]

93. Marshall, C.R. Explaining the Cambrian “explosion” of animals. Annu. Rev. Earth Planet. Sci. 2006, 34, 355-384. [CrossRef]

94. Miljkovic-Licina, M.; Gauchat, D.; Galliot, B. Neuronal evolution: Analysis of regulatory genes in a first-evolved nervous system, the hydra nervous system. Biosystems 2004, 76, 75-87. [CrossRef] [PubMed]

95. Hooshangi, S.; E Bentley, W. From unicellular properties to multicellular behavior: Bacteria quorum sensing circuitry and applications. Curr. Opin. Biotechnol. 2008, 19, 550-555. [CrossRef] [PubMed]

96. Bourret, R.B.; Stock, A.M. Molecular information processing: Lessons from bacterial chemotaxis. J. Biol. Chem. 2002, 277, 9625-9628. [CrossRef] [PubMed]

97. Catterall, W.A.; Wisedchaisri, G.; Zheng, N. The chemical basis for electrical signaling. Nat. Chem. Biol. 2017, 13, 455-463. [CrossRef]

98. Arendt, D.; Bertucci, P.Y.; Achim, K.; Musser, J.M. Evolution of neuronal types and families. Curr. Opin. Neurobiol. 2019, 56, 144-152. [CrossRef]

99. Kristan, J.; William, B. Early evolution of neurons. Curr. Biol. 2016, 26, R949-R954. [CrossRef] [PubMed]

100. Moroz, L.L. On the independent origins of complex brains and neurons. Brain Behav. Evol. 2009, 74, 177-190. [CrossRef] [PubMed]

101. Grillner, S.; Robertson, B. The basal ganglia downstream control of brainstem motor centres-An evolutionarily conserved strategy. Curr. Opin. Neurobiol. 2015, 33, 47-52. [CrossRef] [PubMed]

102. Sarnat, H.B.; Netsky, M.G. When does a ganglion become a brain? Evolutionary origin of the central nervous system. Semin. Pediatr. Neurol. 2002, 9, 240-253. [CrossRef] [PubMed]

103. Jerison, H. Evolution of the Brain and Intelligence; Elsevier: Amsterdam, The Netherlands, 2012.

104. Roth, G.; Dicke, U. Evolution of the brain and intelligence. Trends Cogn. Sci. 2005, 9, 250-257. [CrossRef] [PubMed]

105. Striedter, G.F. Principles of Brain Evolution; Sinauer Associates: Sunderland, MA, USA, 2005.

106. Passingham, R.E.; Wise, S.P. The Neurobiology of the Prefrontal Cortex: Anatomy, Evolution, and the Origin of Insight; Oxford University Press: Oxford, UK, 2012.

107. Florio, M.; Huttner, W.B. Neural progenitors, neurogenesis and the evolution of the neocortex. Development 2014, 141, 2182-2194. [CrossRef]

108. Rakic, P. Evolution of the neocortex: A perspective from developmental biology. Nat. Rev. Neurosci. 2009, 10, 724-735. [CrossRef]

109. Northcutt, R.G.; Kaas, J.H. The emergence and evolution of mammalian neocortex. Trends Neurosci. 1995, 18, 373-379. [CrossRef]

110. Weil, K. Thinking Animals: Why Animal Studies Now? Columbia University Press: New York, NY, USA, 2012.

111. Povinelli, D.J.; Vonk, J. Chimpanzee minds: Suspiciously human? Trends Cogn. Sci. 2003, 7, 157-160. [CrossRef]

112. Lewis, L.P.; Siju, K.; Aso, Y.; Friedrich, A.B.; Bulteel, A.J.; Rubin, G.M.; Kadow, I.C.G. A Higher Brain circuit for immediate integration of conflicting sensory information in drosophila. Curr. Biol. 2015, 25, 2203-2214. [CrossRef]

113. Nuñez, A.; Malmierca, E. Corticofugal modulation of sensory information. Adv. Anat. Embryol. Cell Boil. 2007, $187,1-74$.

114. Kerr, B.J.; Bradbury, E.J.; Bennett, D.L.H.; Trivedi, P.M.; Dassan, P.; French, J.; Shelton, D.B.; McMahon, S.B.; Thompson, S.W.N. Brain-derived neurotrophic factor modulates nociceptive sensory inputs and NMDA-Evoked responses in the rat spinal cord. J. Neurosci. 1999, 19, 5138-5148. [CrossRef] [PubMed]

115. Harter, M.R.; Aine, C.J. Brain mechanisms of visual selective attention. Var. Atten. 1984, $293-321$.

116. Guttorp, P.; Gigerenzer, G.; Swijtink, Z.; Porter, T.; Daston, L.; Beatty, J.; Krüger, L. The empire of chance: How probability changed science and everyday life. J. Am. Stat. Assoc. 1990, 85, 592. [CrossRef]

117. Simberloff, D. A succession of paradigms in ecology: Essentialism to materialism and probabilism. Synthese 1980, 43, 3-39. [CrossRef]

118. Birch, J. Natural selection and the maximization of fitness. Biol. Rev. 2015, 91, 712-727. [CrossRef]

119. Demetrius, L. Directionality principles in thermodynamics and evolution. Proc. Natl. Acad. Sci. USA 1997, 94, 3491-3498. [CrossRef]

120. Purvis, A.; Jones, K.E.; Mace, G.M. Extinction. BioEssays 2000, 22, 1123-1133. [CrossRef]

121. Hart, M.B. Biotic Recovery from Mass Extinction Events; Geological Society of London: London, UK, 1996.

122. Crowley, T.J.; North, G.R. Abrupt climate change and extinction events in earth history. Science 1988, 240, 996-1002. [CrossRef]

123. Raup, D.M. Biological extinction in earth history. Science 1986, 231, 1528-1533. [CrossRef]

124. Benton, M.J. The origins of modern biodiversity on land. Philos. Trans. R. Soc. B Biol. Sci. 2010, 365, 3667-3679. [CrossRef] [PubMed]

125. Courtillot, V.; Gaudemer, Y. Effects of mass extinctions on biodiversity. Nat. Cell Biol. 1996, 381, 146-148. [CrossRef] 
126. Ceballos, G.; Ehrlich, P.R.; Barnosky, A.D.; García, A.; Pringle, R.M.; Palmer, T.M. Accelerated modern human-induced species losses: Entering the sixth mass extinction. Sci. Adv. 2015, 1, e1400253. [CrossRef] [PubMed]

127. Pievani, T. The sixth mass extinction: Anthropocene and the human impact on biodiversity. RENDICONTI Lincei 2014, 25, 85-93. [CrossRef]

128. Crutzen, P.J. The anthropocene. In Earth System Science in the Anthropocene; Springer: Berlin/Heidelberg, Germany, $2006 ;$ pp. 13-18.

129. Bradshaw, C.J.A.; Ehrlich, P.R.; Beattie, A.; Ceballos, G.; Crist, E.; Diamond, J.; Dirzo, R.; Ehrlich, A.H.; Harte, J.; Harte, M.E.; et al. Underestimating the challenges of avoiding a ghastly future. Front. Conserv. Sci. 2021, 1, 9. [CrossRef] 